\title{
UJI KINERJA SCREW OIL PRESS MACHINE DITINJAU DARI RENDEMEN DAN KUALITAS MINYAK KELAPA YANG DIHASILKAN
}

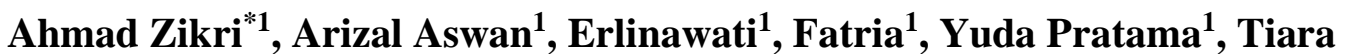 \\ Anggraini $^{1}$, M. Bintang Cendikia ${ }^{1}$ \\ ${ }^{1}$ Program Studi Teknik Energi, JurusanTeknik Kimia, PoliteknikNegeri Sriwijaya \\ Jl. Srijaya Negara Bukit Besar Palembang 30139, Telp +62711353414 / fax +62711355918 \\ *E-mail: ahmad.zikri@polsri.co.id
}

\begin{abstract}
ABSTRAK
Minyak kelapa merupakan salah satu produk utama dari pengolahan daging kelapa melalui proses ekstraksi kering dan basah. Minyak kelapa dapat diproduksi melalui ekstraksi kering kopra mentah dengan perolehan minyak 63-65\%, dan salah satu metodenya adalah dengan cara pengepresan mekanis menggunakan Mesin Screw Press Oil. Pada proses pengepresan, ada banyak faktor yang menyebabkan kehilangan minyak sehingga perolehan produk minyak menjadi lebih sedikit. Pada penelitian ini ditujukan untuk diperolehnya hasil minyak kelapa maksimum dengan mengamati faktor kondisi operasi selama proses pengepresan, seperti kecepatan putar sekrup dan temperatur. Selanjutnya, diperoleh juga jumlah intensitas konsumsi energi dan efisiensi menekan dalam proses produksi minyak kelapa dari bahan baku kopra menggunakan Mesin Screw Press Oil. Metode penelitian dimulai dengan tahap persiapan bahan dan tahap pengujian mesin dengan menganalisis intensitas energi dan efisiensi pengepresan pada Mesin Pengepres Minyak Sekrup yang dibutuhkan dalam proses pengepresan minyak kelapa dari kopra dalam hal hasil minyak kelapa yang dihasilkan.
\end{abstract}

Kata kunci: Mesin press minyak screw, kopra, minyak kelapa.

\begin{abstract}
Coconut oil is one of the main products from processing coconut meat through dry and wet extraction. In dry extraction, coconut oil is produced with raw copra material which has an oil content of $63-65 \%$. The production process of coconut oil from copra is done by mechanical pressing using a Screw Press Oil Machine. In the pressing process, there are many factors that cause oil losses so that the acquisition of oil products becomes less. Therefore, this study aims to obtain maximum coconut oil yield by analyzing several factors of operating conditions during the pressing process such as screw rotational speed and temperature. Furthermor, it is also obtained the amount of energy consumption intensity and pressing efficiency in the production process of coconut oil from copra raw materials using the Screw Press Oil Machine. The research method begins with the preparation stage of the material and the engine testing stage by analyzing the energy intensity and pressing efficiency at the Screw Oil Press Machine needed in the process of pressing coconut oil from copra in terms of the yield of coconut oil produced.
\end{abstract}

Keywords: Screw oil press machine, copra, coconut oil.

\section{PENDAHULUAN}

Indonesia adalah salah satu negara pengekspor terbesar buah kelapa dan olahannya. Pada tahun 2016, produksinya mencapai 18,3 juta Ton yang merupakan tertinggi di dunia 
Akan tetapi, pemanfaatan potensi buah kelapa terbatas dalam bentuk produk primernya saja, masih dalam bentuk daging buah, belum dilakukan pengolahan lebih lanjut yang menyebabkan harga jualnya masih rendah. Berdasarkan data dari Perpekindo, harga buah kelapa masih dibawah Rp. 1.000 per butirnya di beberapa daerah di Indonesia, seperti provinsi Suamtera Selatan, Jambi, Kalimantan, Palu dan Gorontalo. Oleh karenanya, dibutuhkan hilirisasi dan penganekaragaman produk olahan buah kelapa untuk diperolehnya nilai ekonomi yang lebih baik, seperti dengan diproduksinya minyak kelapa.

Minyak kelapa adalah salah satu produk yang dihasilkan dari daging buah kelapa (Cocos nucifera L.). Minyak kelapa dapat diperoleh dengan cara mengeringkan melalui proses pemanasan hasil perasan santan daging buah kelapa. Kandungan dari daging buah kelapa adalah terdiri atas air $46 \%$, lemak $34,7 \%$, protein $3,4 \%$ dan karbohidrat 14,0\% (Nasruddin, 2011).

Minyak kelapa memiliki warna kuning muda kecokelatan dan bening. Titik bekunya di temperatur $18-20^{\circ} \mathrm{C}$, dan kembali mencair pada temperatur $23-26^{\circ} \mathrm{C}$. Berat jenisnya sekitar $0,91-$ $0,93 \mathrm{gr} / \mathrm{ml}$, tergantung pada kondisi temperaturnya. Kandungan lemak di minyak dari olahan kopra antara 60$65 \%$, dan sedangkan di buah segarnya (daging putih kelapa) adalah sekitar $43 \%$ (Sulastri, 2015).

Minyak kelapa telah diketahui memiliki kegunaan yang berlimpah di bidang kesehatan dan juga kecantikan. Minyak yang terkategori nabati ini secara umum tersusun dari senyawa trigliserida yang 90\%-nya didominasi oleh asam lemak bebas (Polii, 2016). M inyak kelapa sendiri memiliki panjang rantai karbon medium dengan 12 atau lebih atom karbon yang terikat jenuh karena tidak memiliki ikatan rangkap di dalamnya (Sidabutar,2015).

Produksi minyak kelapa ini dapat dilakukan dengan beberapa cara dan salah satunya adalah melalui ekstraksi kering daging kelapa (kopra). Kopra adalah produk daging kelapa yang dikeringkan. Kopra bermutu rendah akan menghasilkan minyak kelapa kasar bermutu rendah, yang diindikasikan minyak berwarna coklat, kadar asam lemak bebas tinggi dan berbau tengik (Lay dan Maskromo, 2016)

Penelitian ini menggunakan mesin pengepres berulir atau screw dengan bahan baku padat berupa kopra. Kopra akan diperas oleh screw press dengan hasilnya berupa minyak kelapa dan ampas padat. Peneliti mencoba untuk menganalisis pengaruh putaran ulir dan temperatur pengepresan yang paling efektif digunakan dalam menghasilkan minyak kelapa, selajutnya diperoleh intensitas konsumsi energi dan efisiensi pengepresan untuk dihasilkannya rendemen minyak yang maksimal.

Faktor terpenting di dalam penentuan kualitas minyak kelapa adalah didasarkan standar mutunya, meliputi kandungan kadar air, kadar asam lemak bebas, bilangan peroksida dan kadar kotoran. Pemerintah telah menetapkan SNI-Minyak Kelapa 01-2902-1992 (tabel 1) sebagai persyaratan teknis atau kriteria yang harus terpenuhi di dalam minyak kelapa.

Tabel 1. Syarat Mutu Minyak Kelapa

\begin{tabular}{lc}
\hline \multicolumn{1}{c}{ Parameter } & Nilai \\
\hline Air & maks. 0,5\% \\
Kotoran & maks. 0,05\% \\
Bilangan Peroksida (mg & \\
O2/gram sampel) & maks. 5,0 \\
$\begin{array}{l}\text { Asam lemak bebas (asam } \\
\text { laurat) } \\
\text { Minyak pelikan }\end{array}$ & maks 5\% \\
\hline \multicolumn{2}{c}{ (Badan Standarisasi Nasional, 1992) }
\end{tabular}

(Badan Standarisasi Nasional, 1992) 
Kopra merupakan daging buah kelapa yang telah dikeringkan melalui proses pengasapan, panas matahari, ataupun dengan panas buatan. Metode penanganan dalam memproduksi kopra ini sangatlah menentukan jumlah dan kualitas minyak yang dihasilkan. Kopra dari pengeringan dengan panas matahari produk minyak-nya cenderung bewarna bening bersih. Namun metode ini sangatlah tidak efektif dan tidak efisien karena terkait kestabilan pencahayaan panas matahari di lingkungan, khususnya proses pengeringan yang dilakukan disaat musim penghujan. Sedangkan pengeringan melalui proses pengasapan dihasilkan minyak kelapa dengan kualitas yang lebih rendah. Persyaratan kualitas kopra di perdagangannya adalah berkadar asam lemak bebas dengan nilai maksimum 4\%. Satu kilogram kopra dibutuhkan kurang lebih 6-8 butir buah kelapa, dan bergantung pada besar dan ketebalan dagingnya (Amin, 2009).

Daging buah kelapa basah biasanya masih mengandung sekitar 50\% dan $30 \%$ minyak, dan yang dijadikan kopra oleh para petani kelapa adalah berkisar $15-22 \%$ kadar airnya. Kopra kering memiliki kandungan mineral 2-3\% dan sudah layak untuk dilakukan proses penyimpanan dalam kondisi ruang. Kadar air adalah sangat menentukan mutudari produk olahan kopra, dari segi kualitas maupun kuantitas minyak yang akan diperoleh. Hal ini disebabkan oleh mudah rusaknya kopra yang masih basah oleh mikroorganisme di saat proses penyimpanan maupun saat pengolahannya menjadi minyak. (Handayani, 2008).

\section{Pengepresan berulir (screw pressing)}

Ekstrasi minyak dengan menggunakan mesin pengepresan berulir bekerja dengan proses pelumatan dan penekanan daging kopra dalam tabung yang berlubang dengan aliran berputar mengikuti arah ulir, sehingga minyak akan keluar melewati lubang-lubang tabung. Besarnya tekanan alat ini dapat diatur secara elektris, dan tergantung dari volume bahan yang akan dipres. Pengepresan berulir menghasilkan kadar air di dalam minyak berkisar sekitar 2,5$3,5 \%$, sedangkan bungkil yang dihasilkan masih mengandung minyak sekitar 4-5\%. Alat pengepress jenis ini memanfaatkan putaran dari double scew press dan scew press cage.

\section{Intensitas Konsumsi Energi}

Intensitas Konsumsi Energi (IKE) adalah parameter utama yang harus diperoleh untuk menentukan tingkat efisiensi suatu unit kerja. Dengan nilai IKE ini dapat membantu proses analisis peluang penghematan energi.

$\mathrm{IKE}=\frac{\text { Total energi yang dikonsumsi }}{\text { Total massa bahan yang dihasilkan }}$

(Kementrian Perindustrian, 2011)

IKE ini merupakan jumlah konsumsi energi per setiap kali alat berproduksi. Semakin rendah angka intensitas energi, semak inefisien penggunaan energinya.

\section{Efisiensi Pengepresan}

Efisiensi pengepresan diukur berdasarkan jumlah produk yang dihasilkan dari proses pengepresan. Faktor yang mempengaruhi jumlah minyak yang akan diperoleh dari proses pengepresan mekanis berulir adalah sebagai berikut:

a) Ukuran kopra

Kopra yang berukuran besar harus dicacah atau dikecilkan terlebih dahulu sehingga dapat mudah ditekan dan diekstrak minyaknya, dan untuk meningkatkan rendemen minyak yang diperoleh.

b) Kandungan air

Kandungan air kopra berpengaruh secara signifikan terhadap rendemen minyak hasil pengepresan. Toleransi 
bahan biji-bijian untuk diambil minyaknya secara pengepresan ini adalah bervariasi, misalnya untuk biji bunga matahari maksimum $6 \%$, kedelai berkisar 9,5-10\% dan untuk conophor nut berkisar 8-10\%. (Amin, 2009)

c) Temperatur dan waktu pemanasan

Temperatur dan waktu pemanasan mempengaruhi rendemen, karena dengan pemanasan ini dapat berakibat terhadap pemecahan sel tumbuh di dalam biji, dan juga dapat terjadinya koagulasi protein dalam biji yang berakibat turunnya viskositas minyak dan akan mempercepat aliran minyak keluar. Temperatur dan waktu pemanasan yang diperlukan adalah tergantung pada jenis biji tumbuhan yang akan diolah, misalnya pada biji kedelai pada suhu $65^{\circ} \mathrm{C}$. Temperatur yang tinggi dan waktu pemanasan yang lama akan mungkin berpengaruh pada kualitas cake oil dan minyak hasil pengepresan. d) Tekanan

Rendemen minyak yang diperoleh berbanding lurus dengan besar tekanan pengepresan yang diberikan. Misalkan, biji bunga matahari membutuhkan tekanan sekitar 15 MPa. Semain lama waktu pengepresan akan menurunkan kualitas minyak dikarenakan mempercepat terjadinya ketengikan (Estrada dkk., 2017).

\section{METODOLOGI PENELITIAN Proses Pengepresan}

Kopra yang telah diperkecil ukurannya/diparut dimasukkan ke dalam funnel pada Screw Oil Press Machine. Selanjutnya, mengatur kondisi operasi yang akan digunakan berupa kecepatan putar ulir dan temperature pengepresan. Minyak kelapa yang telah keluar ditampung di wadah penampung dan dihitung persen rendemennya.

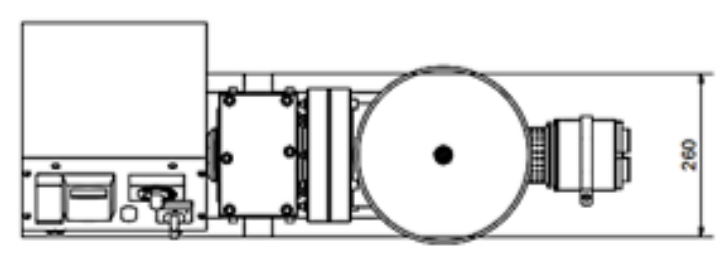

(a)

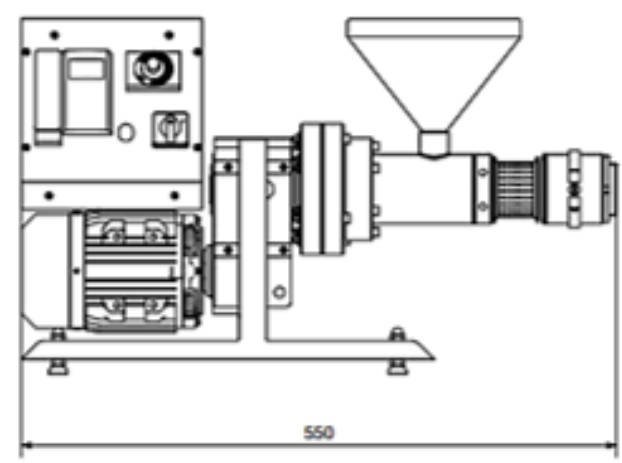

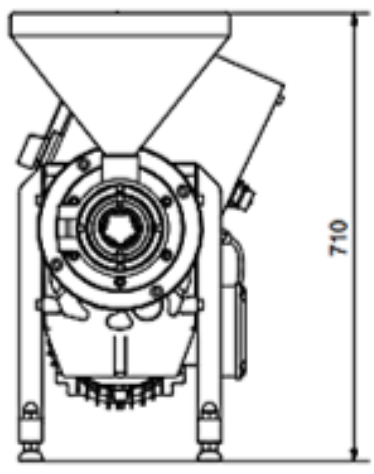

(b)

(c)

Gambar 1. (a) Tampak atas, (b) Tampak samping, (c) Tampak depan Screw Oil Press Machine 


\section{Analisis Produk}

Kualitas minyak ditinjau dari kandungan kadar air, kadar asam lemak bebas, angka peroksida, dan kadar kotoran minyak kelapa. Analisis kualitas minyak kelapa ini disesuaikan dengan SNI 01-2902:1992.

\section{HASIL DAN PEMBAHASAN Hasil}

Data yang didapat pada penelitian ini diambil secara langsung oleh peneliti dengan melakukan percobaan terhadap Screw Oil Press Machine sebagai alat pengepresan mekanik tipe ulir. Pada penelitian ini menggunakan bahan baku kopra yang diambil minyaknya sebagai produk.

\section{Pembahasan}

Beberapa pengukuran telah dilakukan untuk mengetahui hubungan antara temperatur pengepresan terhadap rendemen yang dihasilkan serta serta dilakukannya uji kinerja pada Screw Oil Press Machine berdasarkan Intensitas Energi dan Efisiensi Pengepresan yang didapatkan.

\section{Hubungan Temperatur Pengepresan dan Kecepatan Putir Ulir terhadap Rendemen Minyak Kelapa yang dihasilkan}

Gambar 2 menunjukkan grafik perbandingan penggunaan temperatur pengepresan dan kecepatan putar ulir alat pengepresan berulir terhadap rendemen minyak kelapa yang diperoleh. Pada pengaruh kecepatan putar ulir terhadap rendemen minyak kelapa didapatkan rendemen yang terus meningkat seperti yang terlihat pada Gambar 2. Kecepatan putaran screw selain sebagai driving force juga meningkatkan ekspansi massa padatan daging buah serta mempercepat pengeluaran ampas.

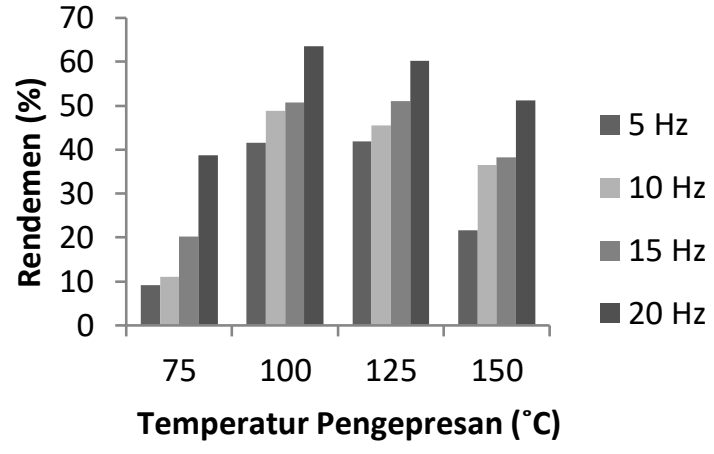

Gambar 2. Grafik Hubungan Antara Temperatur Pengepresan dan Kecepatan Putar Ulir Terhadap Rendemen Minyak Kelapa

Apabila kecepatan putaran screw diperlambat maka akan terjadi kehilangan tenaga untuk proses penekanan (pengepresan) sehingga minyak yang dihasilkan rendah, sedangkan jika kecepatan putar screw dipercepat maka aliran masa melalui ujung outlet dipercepat pula sehingga hanya sebagian kecil kopra yang terekstrak.

Temperatur pengepresan juga mempengaruhi jumlah rendemen minyak kelapa yang dihasilkan. Menurut Arlene dkk. (2010), semakin tinggi temperatur pengepresan menghasilkan rendemen yang semakin tinggi juga karena dengan proses pemanasan minyak menjadi cair dan viskositas minyak akan berkurang sehingga lebih memudahkan minyak untuk mengalir keluar dari matriks sel-sel kopra. Namun, pada temperatur pengepresan di atas $100^{\circ} \mathrm{C}$ rendemen minyak kelapa mengalami penurunan. Hal dapat terjadi karena tingginya temperatur pengepresan yang menyebabkan kandungan air dalam bahan menjadi berkurang, sehingga volume minyak kelapa yang dihasilkan pun berkurang. Pada penelitian yang dilakukan oleh Galuh dan Vita (2016) juga dinyatakan bahwa temperatur mempengaruhi perolehan minyak pada proses pengepresan. 


\section{Hubungan Temperatur Pengepresan dan Kecepatan Putir Ulir terhadap Intensitas Energi}

Indikator efisiensi energi yang digunakan pada penelitian ini adalah intensitas energi. Intensitas energi diperoleh dari perhitungan total penggunaan energi listrik saat penggunaan alat pengepresan berulir di dalam memproduksi minyak kelapa. Dari Gambar 3 dapat dilihat grafik yang cenderung menurun seiring dengan meningkatnya kecepatan putar ulir. Intensitas energi tertinggi didapatkan pada temperatur $75^{\circ} \mathrm{C}$ dengan kecepetan putar ulir $5 \mathrm{~Hz}$.

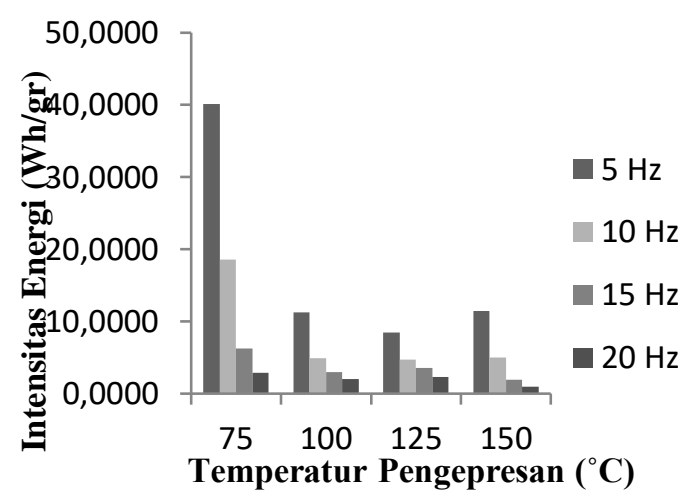

Gambar 3. Grafik Hubungan Antara Temperatur Pengepresan dan Kecepatan Putar Ulir Terhadap Intensitas Energi

Sedangkan intensitas energi terendah didapatkan pada temperatur $150^{\circ} \mathrm{C}$ dengan kecepatan putar ulir $20 \mathrm{~Hz}$. Berdasarkan pengamatan diketahui bahwa semakin tinggi kecepatan putar ulir dari alat pengepres, akan semakin tinggi konsumsi listriknya, serta mengakibatkan intensitas energinya semakin menurun. Hal ini dikarenakan semakin tinggi kecepetan putar ulir maka waktu pengepresan yang dibutuhkan lebih singkat dan minyak yang dihasilkan lebih banyak dengan adanya pemanasan. Karena waktu pengepresan yang dibutuhkan lebih sedikit untuk mengahasilkan minyak lebih banyak menandakan bahwa penggunaan energi yang lebih efisien sehingga intensitas energinya lebih kecil.

\section{Hubungan Temperatur Pengepresan dan Kecepatan Putir Ulir terhadap Efisiensi Pengepresa Minyak Kelapa}

Efisiensi pengepresan merupakan parameter penting untuk meninjau kinerja dari Screw Oil Press Machine yangmana fungsi utama dari alat ini ialah mengekstrak minyak dari bahan serta menghasilkan biopelet. Maksud dari efisiensi disini adalah persen perbandingan antara jumlah produk minyak hasil pengepresan dengan kandungan minyak pada kopra berdasarkan teori. Dikutip dari artikelnya yang berjudul beberapa metode pembuatan minyak kelapa, Sulastri (2015) menuliskan; umumnya, kopra mengandung minyak antara 60$65 \%$. Pernyataan ini dijadikan sebagai dasar untuk menghitung nilai efisiensi dengan menggunakan kandungan minyak kopra secara teori tertinggi yaitu $65 \%$ untuk dihitung efisiensinya sehingga didapatkanlah grafik seperti yang terlihat pada Gambar 4 .

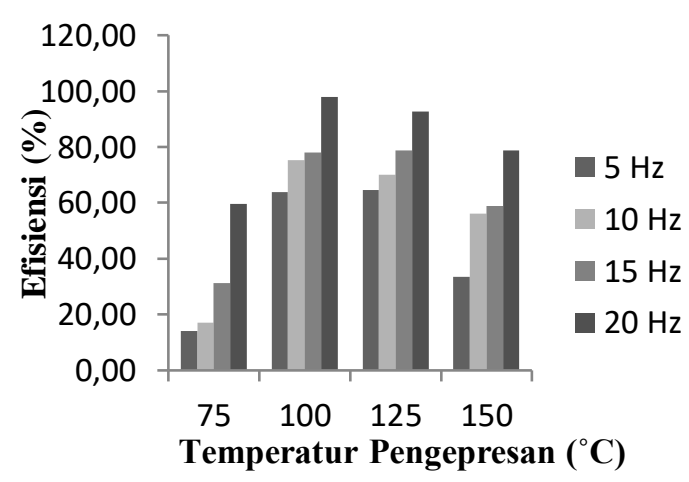

Gambar 4. Grafik Hubungan Antara Temperatur Pengepresan dan Kecepatan Putar Ulir Terhadap Efisensi

Grafik yang diperoleh menggambarkan bentuk yang sama dengan grafik yang digambarkan oleh rendemen minyak kelapa. Hal ini dikarenakan perhitungan efisiensi dilakukan dengan 
menggunakan data hasil rendemen dan dibandingkan dengan kandungan minyak kopra secara teori yang merupakan variabel tetapnya. Sama halnya dengan rendemen, efisiensi tertinggi dimiliki oleh kondisi operasi pada temperatur pengepresan $100^{\circ} \mathrm{C}$ dengan kecepatan putar ulir $20 \mathrm{~Hz}$ yang menghasilkan rendemen tertinggi, dan efisiensi terendah dimiliki oleh kondisi operasi pada temperatur pengepresan $75^{\circ} \mathrm{C}$ dengan kecepatan putar ulir $5 \mathrm{~Hz}$.

Efisiensi pengepresan memiliki beberapa faktor seperti ukuran bahan, kadar air bahan, temperatur pengepresan, dan tekanan. Ukuran bahan yang relatif besar harus di perkecil agar mudah dilakukan penekanan dan akhirnya akan meningkatkan rendemen yang berpengaruh pula terhadap peningkatan efisiensi. Kadar air berpengaruh secara signifikan terhadap perolehan rendemen minyak pengepresan. Temperatur pemanasan juga mempengaruhi rendemen, dikarenakan pemanasan dapat memecah sel bahan yang akan mengkoagulasi protein dari kopra, dan mengakibatkan viskositas minyak akan turun dan akan mempercepat aliran minyak keluar. Sehingga semakin tinggi temperatur akan semakin banyak minyak yang diekstrak dari bahan dan hampir mendekati nilai kandungan minyak secara teori tertinggi berdasarkan tulisan Sulastri (2015) yang menyebabkan efisiensi meningkat. Namun temperatur yang terlalu tinggi juga dapat menyebabkan rendemen minyak yang dihasilkan menurun, karena dapat mengakibatkan air dalam kopra menjadi menguap sehingga efisiensi akan menurun pada temperatur yang terlalu tinggi. Kecepatan putaran screw memberikan tenaga untuk proses pengepresan, sehingga minyak akan keluar dari bahan, karenanya kecepatan putaran screw yang meningkat menyebabkan peningkatan efisiensi alat.

\section{Analisis Kualitas Minyak Kelapa Hasil Pegepresan}

Tabel 2. Hasil Karakterisasi Minyak Kelapa

\begin{tabular}{lcccc}
\hline \multirow{2}{*}{ Karakteristik } & \multicolumn{4}{c}{ TemperaturPengepresan $\left({ }^{\circ} \mathrm{C}\right)$} \\
\cline { 2 - 5 } & 75 & 100 & 125 & 150 \\
\hline $\begin{array}{l}\text { Kadar Air (\%) } \\
\text { Kadar ALB } \\
(\%)\end{array}$ & 1,80 & 0,78 & 0,41 & 0,35 \\
$\begin{array}{l}\text { Angka } \\
\text { Peroksida } \\
(\text { mgO } / \text { gr) }\end{array}$ & 0,24 & 0,44 & 0,32 & 0,28 \\
$\begin{array}{l}\text { Kadar Kotoran } \\
(\%)\end{array}$ & 0,039 & 0,045 & 0,048 & 0,10 \\
$\begin{array}{l}\text { Densitas } \\
(\text { gr/mL) }\end{array}$ & 0,96 & 0,95 & 0,95 & 0,97 \\
$\begin{array}{l}\text { Viskositas } \\
(\mathrm{cP})\end{array}$ & 30,16 & 31,75 & 31,18 & 30,9 \\
\hline
\end{tabular}

Kualitas minyak kelapa diuji berdasarkan SNI 01-2902:1992. Dari hasil penelitian yang dilakukan, temperature memiliki pengaruh terhadap karakteristik minyak kelapa hasil pengepresan. Dari hasil penelitian, minyak kelapa yang memiliki kualitas yang sesuai dengan SNI 01-2902:1992 adalah pada pengepresan pada temperatur $125^{\circ} \mathrm{C}$.

\section{SIMPULAN}

Perubahan temperatur pengepresan dan kecepatan putar ulir dalam proses pengepresan kopra menggunakan Screw Oil Press Machine untuk dihasilkannya produk berupa minyak kelapa, dapat disimpulkan bahwa rendemen minyak kelapa tertinggi didapatkan pada temperatur pengepresan $100^{\circ} \mathrm{C}$ dengan kecepatan putar ulir $20 \mathrm{~Hz}$, yaitu sebesar $63.62 \%$. Dari segi efisiensi energinya, ditinjau berdasarkan intensitas konsumsi energi pada proses pengepresan minyak kelapa, ini didapatkan nilai intensitas energi tertinggi pada temperatur $75^{\circ} \mathrm{C}$ dengan kecepetan putar ulir $5 \mathrm{~Hz}$ dan intensitas energi terendah didapatkan 
pada temperatur $150^{\circ} \mathrm{C}$ dengan kecepatan putar ulir $20 \mathrm{~Hz}$.

Dari segi keefektifan proses pengepresan minyak kelapa dapat dilihat berdasarkan nilai efisiensinya. Sama halnya dengan rendemen, efisiensi tertinggi dimiliki oleh kondisi operasi pada temperatur pengepresan $100^{\circ} \mathrm{C}$ dengan kecepatan putar ulir $20 \mathrm{~Hz}$ yang menghasilkan rendemen tertinggi, dan efisiensi terendah dimiliki oleh kondisi operasi pada temperatur pengepresan $75^{\circ} \mathrm{C}$ dengan kecepatan putar ulir $5 \mathrm{~Hz}$. Untuk menjaga kualitas minyak kelapa agar tetap sesuai dengan SNI 012902:1992, pengepresan minyak kelapa dilakukan pada temperatur $125^{\circ} \mathrm{C}$.

\section{DAFTAR RUJUKAN}

Amin, S. 2009. Cocopreneurship. Aneka Peluang Bisnis dari Kelapa.

Arlene, A.; Suharto, I.;\& Jessica, N.R., 2010. Pengaruh Temperatur dan Ukuran Biji Terhadap Perolehan Minyak Kemiri pada Ekstraksi Biji Kemiri dengan Penekanan Mekanis. Prosiding Seminar Nasional Teknik Kimia "Kejuangan". F04-1 - F04-6.

Estrada, F.; Gusmao, R.; Mudjijati.;\& Indraswati, N. 2007. Pengambilan Minyak Kemiri dengan Cara Pengepresan. 6, 121-130.

Handayani. 2008. Perbandingan Pengolahan VCO Proses Basah Dan Prosess Kering Terhadap Rendemen Dan Kualitasnya. Politeknik Negeri Samarinda

Kementrian Perindustrian. 2011. Pedoman Teknis Audit Energi dalam Implementasi Konservasi Energi dan Penggunaan Emisi $\mathrm{CO}_{2}$ di Sektor Industri. Pusat Pengkajian Industri Hijau dan Lingkungan Hidup

Lay, A.; \& Maskromo, A. 2016. Kinerja Alat Pengeringan Kopra Sistem
Oven Skala Kelompok Tani dan Karakteristik Produk. Balai Penelitian Tanaman Palma, 175183.

Nasruddin.2011. Studi Kualitas Minyak Goreng dari Kelapa (Cocos nucifera L.) melalui Proses Sterilisasi dan Pengepresan. Dinamika Penelitian Industri, 22, 9-18.

Polii, F. F. 2016. Pemurnian Minyak Kelapa dari Kopra Asap dengan Menggunakan Adsorben Arang Aktif dan Bentonit. Jurnal Riset Industri, 10(3), 115-124.

R.P.; Galuh Chynintya.;\& Paramita, Vita. 2016. Pengaruh Temperatur, Kecepatan Putar Ulir dan Waktu Pemanasan Awal terhadap Perolehan Minyak Kemiri dengan Metode Penekanan Mekanis (Screw Press). METANA, Universitas Diponegoro, vol. 12, 17-25.

Sidabutar, Devika Y. 2015. Penetapan Kadar Asam Lemak Bebas pada Minyak Kelapa Murni (Virgin Coconut Oil). Universitas Sumatera Utara

Sulastri, S. 2015. Beberapa Metode Pembuatan Minyak Kelapa. PPM FMIPA UNY. Yogyakarta. 